\title{
THE ROLE OF ONLINE ENGLISH COMMUNITY DURING COVID-19 PANDEMIC
}

\author{
Siti Hadianti ${ }^{1}$, Bobi Arisandi ${ }^{2}$ \\ ${ }^{1}$ English Education Department, Universitas Terbuka, Indonesia \\ ${ }^{2}$ English Department, Universitas Pamulang, Indonesia \\ E-mail: sitihadianti@ecampus.ut.ac.id
}

Received: 26 October 2020

Accepted: 08 December 2020

\begin{abstract}
The outbreak of coronavirus disease 2019 (COVID-19) has caused many new challenges for educational institutions. Most schools and universities have been transforming the learning mode into an online platform and it leaves teachers and students in a challenging situation. The existence of English community which helped to provide exposure and practice toward English learning is postponed due to COVID-19 pandemic. Online English community as an alternative to replace English community has not been observed well before. Its flexibility in learning is assumed that it can enhance a better engagement in the English learning activity. The purpose of this study is to investigate the role of the online English community during COVID-19 pandemic. Fifteen university students that are involved in one online English community participated in the research. The researchers chose the sample by using purposive sampling. The data was collected through questionnaire and interview and the method that is used is qualitative research with a case study design. The researchers found that there are at least 3 roles of online English community during COVID-19 pandemic.
\end{abstract}

Keywords: Covid-19 pandemic, teaching learning activity, online learning platform.

\section{Introduction}

The coronavirus outbreak that happens recently all over the world brings a new phenomenon in people's life. The pandemic started in the city of Wuhan, Hubei province, China and has brought many new challenges to many sectors in various countries. Indonesia is the fourth most populous country in the world, and thus is predicted to suffer greatly and over a longer time period, when compared to other less-populous countries (Djalante, 2020). One of the sectors that experience quite significant changes is education. According to Rahiem (2020), because of the threat posed by COVID-19, educational institutions have transformed its teaching learning activity into virtual classrooms. Schools and universities have decided to cancel all face-to-face classes, including laboratories and other learning activities. Students are also required to study from home to help avoid the spread of the coronavirus.

In Indonesia, the closure on schools in some provinces, e.g. DKI Jakarta, Central Java, Banten, West Java, and Aceh started on March 16, 2020 meanwhile nationwide school closures began on March 23, 2020 (Kumparan, 2020). It has given impact to millions of 
learners and educators who study or teach at 425,451 educational institutions from early childhood to higher education.

Responding the issue, the Minister of Education and Culture of Republic of Indonesia has given instructions to schools to carry out online learning since 17 March 2020 for COVID19 affected areas. Soon after that, all education units have been ordered to run online learning form due to the increasing spread of COVID-19. These policies lead students to learn from home with various online learning platform.

However, teaching through online mode is not ideal for English language learning. To acquire English language, learners are demanded to have a lot of exposure and practices which lack to be provided by the schools' e-learning system. Students need to experience real communication and practice their English with lecturer or their peer which is now difficult to do. According to Bahar (2014), many studies show that the level of communicative competence in English demonstrated by many university graduates is still very low. The fact shows that almost all English learners spend their time on studying English in the classrooms. Meanwhile, students need various exposure to improve their English skills.

In line with the problem above, the challenges may emerge in the online EFL learning from the students' point of view. The first problem is that some students do not have their own smartphone. It is usually caused by the financial condition of their family. The second one is about the unstable internet connection. The cellular signal and internet coverage still become a problem in remote and rural areas. In fact, some students live in remote, rural, and mountainous areas. The financial condition of the students and their family also generate another problem that is the inability to afford sufficient mobile data for online learning. They can only afford a small internet mobile data that is not enough to take part in the online learning comfortably. Many students have low digital literacy. They find difficulties in operating the applications and platforms used for online learning. A logical reasoning behind this is that the students did not use to learn through online learning and interact with those applications and platforms. All the problems mentioned previously brings students into limited exposure in learning.

Referring to the problem mentioned above, it is expected that English community can provide sufficient learning exposure because it focuses on practice and improve their English skills. Unlike learning activities from university that depend on the curriculum, learning through English community is more flexible in term of location and time. The phenomenon of English community occurs because in Indonesia, English is taught and learnt as a foreign language.

Being part of a community is important for language learning because students can get immersed in the learning process. Traditionally, students involved in a community with a face to face mode. Because of today's situation, English community needs to be transformed into the online mode. An online community is defined as a group of individuals who get together for a specific purpose to exchange opinions and ideas or to satiate particular needs. They are directed by formal and/or informal rules and policies and supported by computermediated technology (Jones \& Preece, 2006). The online English community is assumed can sustain the benefit of English community as a supplement to English learning.

By establishing an online English community, it hopes to preserve the role of traditional English community in the same way. It is also expected to work well in term of supporting teaching and learning. Many studies have been conducted to explore the English language learning in covid 19 outbreak. One of the research conducted by Nur Agung (2020) entitled 
"Students' Perception of Online Learning during COVID - 19 Pandemic: A Case Study on the English Students of STKIP Pamane Talino" identified three major obstacles in conducting online learning in English Language Education Study Program at STKIP Pamane Talino. Another study by Atmojo (2020) entitled "EFL Classes Must Go Online! Teaching Activities and Challenges during COVID-19 Pandemic in Indonesia" focus on the EFL online class. However, there is lack of attention that had been put on the role of online English community during pandemic. Therefore, this present study investigates the role of online English community during COVID-19 pandemic.

\section{Literature Review}

\subsection{Online Learning}

In the modern era, learning can be done through online platform. Online learning derives as process of learning which is conducted in such a networking environment. As it is stated by Singh \& Thurman in Dhawan, (2020), online learning is defined as:

"learning experiences in synchronous or asynchronous environments using different devices (e.g., mobile phones, laptops, etc.) with internet access. In these environments, students can be anywhere (independent) to learn and interact with instructors and other students"

In line with explanation above, implementation of online learning performs in various type such as website, application, email, and virtual conferences. According to Dhull (2017), online learning encompasses a range of technologies such as the worldwide web, email, chat, new groups and texts, audio and video conferencing delivered over computer networks to impart education. It means in application all learning process in form of internet based can be called as online learning.

Atmojo (2020) states that teachers perform the online learning in synchronous mode and asynchronous mode. The synchronous mode means that the teachers carry out online learning at certain time in a week. Meanwhile, the asynchronous mode means that the teachers hold the online learning in a range of longer period, one week for instance. From the description, asynchronous mode is more flexible than the synchronous. This condition also applies in higher education system. University fully replaces face-to-face learning in classroom setting into online learning which possibly lasts till the end of semester due to the COVID-19 pandemic.

During pandemic, online learning become more and more developed. However, the existence of online learning happens long before that. Universities tend to adopt online learning since it can provide a better learning environment for students in term of accessibilty and flexibility (Roddy, 2017). This claim is supported by Brown (2011) who argues that accessing course materials online allows unprecedented levels of flexibility and accessibility for students from around the world and overcomes geographical barriers that might prevent students accessing on-campus course offerings.

Based on all theories above, the researchers redefine the definition of online laerning. Researcher concludes that online learning is all process of transfering knowledge and value using internet-based platform. This definition is partially used to define online English community due to the lack of literature concerning that matter. 


\subsection{English Community}

English community is a term that commonly used by EFL learner in Indonesia. It refers to a group of people who are willing to improve and regularly practice their English. Cobigo (2020) defines community as a group of people that interact and support each other, and are bounded by shared experiences or characteristics, a sense of belonging, and often by their physical proximity. In other words, community may be understood as a group of individuals who live in the same territory, share a particular interest in common, and display a sense of belonging to the place where they live. Being part of a community is important for language learning because students can get immersed in the learning process.

The phenomenon of English community is widely spread in indonesia from primary to tertiary or university level. According to Sargsyan and Kurghinyan (2016), this is interesting because a current phenomenon shows a unique tendency where many young EFL learners prefer to practice English outside the classroom than in the classroom. It can be understood since English is the official language in Indonesia, but there is limited learning exposure. To prevent that problem, English community can be a good solution.

Unfortunately, during COVID-19 pandemic, English community could not carry out the learning activity. Unlike formal learning, English community is informal, and it is not supported by sophisticated technology that can sustain the activity. In this research, researcher try to see the possibility of online English community whether it can work as good as conventional English community.

\section{Research Method}

The purpose of this study is to explore the role of online English community during COVID-19 pandemic. Based on this goal, the researcher used qualitative approach with a case study method as a design. As supported by Creswell (2014) that "qualitative research is a means for exploring and understanding the meaning individuals or group ascribe to a social or human problem". In this study, the researcher focused on phenomenon that happened in one online English community.

Initially, this English community is an English course established by an English lecturer in one of the private universities in Lampung. It is now functioned as an online English community where anyone can join. To join with the community, participant has to register online without fee charge. The online English community held its class once a week for an hour through WhatsApp. They now have $\mathbf{4 0}$ members and always engage in active lessons.

The researcher used purposive sampling to choose the participants of the study. Palys (2008) defines purposive sampling as virtually synonymous with qualitative research. Purposive sampling signifies that one sees sampling as a series of strategic choices about with whom, where and how one does one's research. This statement implies that the way where the researchers take the sample must be tied to the objectives. The respondents of the research were 15 university students of English Education department. The researcher approaches the issue by using qualitative method. The data collecting techniques that the researcher used including questionnaire interview. For the questionnaire, the researcher asked the participants to answer several questions. The second data collecting technique that is used by the researcher was interview. It consists of several questions that are relevant to the research question. 


\section{Results and Discussion}

The results of this research is relevant to answer the research questions on the role of online English community during the COVID-19 pandemic. There are 3 (three) roles that will be discussed. The first role is as a medium of English exposure and practice in English language learning. Second, to motivate students to learn better and the last can be an additional medium to share various information.

\subsection{Medium of English exposure and practice}

The first role of online English community is an easy medium of English exposure and practice. Since English language learning demands a lot of exposure, providing a learning medium as supplement is necessary. However, this is difficult to be done since lecturers already feel overwhelmed to have more responsibility. By having online English community, it facilitates students to practice and get exposure easily. Online English community is an informal community where students do not have to think and worry about the score. So, its learning mode also more flexible. Tutor can use many kind of learning mode including WhatsApp application. Students can express their interest in learning without burden. Students are given opportunity to learn easier since the community only used WhatsApp platform in conducting the activity. In the usual online classroom, students have to be ready if they need to have online meeting by using video meeting platform, such as Zooms. They do not always have good signal and internet mobile data. So, the online English community can be alternative for them.

The idea that online English community can be a medium of English exposure and practice is expressed in the excerpt below.

$\begin{array}{ll}\text { Student 1 } & : \quad \begin{array}{l}\text { Yeah it really helps me. Because I can keep } \\ \text { practicing my English. }\end{array} \\ \text { Student } 2 & : \quad \begin{array}{l}\text { It really helps me. The tutor in the community } \\ \text { gives many exercises like TOEFL, finding the }\end{array} \\ \text { verbs, and guess the star. } & \begin{array}{l}\text { Here, I find many strategies in learning and } \\ \text { increase my vocabulary. }\end{array}\end{array}$

Based on the excerpt, it is known that online English community can help students to explore more regard to their English practice. It happens since it provides various activity which increase the level of exposure toward English language. In this online English community, teachers give several topics mostly by using games. For example, they play what so called as "Guess the Stars". Here, teacher gave example of maximum 3 sentences that describe someone uniqueness. Other participants have to guess the star that is being discussed. This strategy has raised students' activeness by trying to answer. Beside that, this strategy can also enhance students' writing skill.

Another topic is "Find the Verbs". With this topic, students are expected to listen to the song audio recording and find all the verbs through the lyrics. Teachers provide students with a short audio clip from famous singer. The purpose of this strategy is for students to practice their listening skills and improve students' vocabulary by finding the past form of the verbs.

The role of online English community as medium of learning exposure and practice happens because it only needs low cost during the activity. Online learning actually provides process of learning with exposure and practice; however, since the process demands good 
internet connection, it puts burdens on students. Students need to have a good internet connection which is not free and difficult for them due to financial disadvantages. The condition explained in the excerpt below.

Student $1:$ I feel difficult to understand the material
without direct explanation or face to face and I
am not satisfied. Then, internet data which is
used also burden me, especially in the learning
session that using hard application (ex: zoom).
But, if only wa, I'm okay.

\subsection{Motivate students to learn better}

Not only delivering the knowledge, the teacher also always gives motivation to the students on how to improve their English skills. The second role of online English community is it can motivate students to learn better. It can be seen from the transcript that the students are helped by the teacher in improving their motivation in learning English.

\begin{tabular}{|c|c|c|}
\hline Student 1 & : & $\begin{array}{l}\text { This community helped me through an online } \\
\text { class and gained my spirit to learn English } \\
\text { even I just learn from home and didn't meet } \\
\text { others. }\end{array}$ \\
\hline Student 2 & • & $\begin{array}{l}\text { This community helped me to keep learning } \\
\text { English and I feel enjoy. }\end{array}$ \\
\hline Student 3 & & $\begin{array}{l}\text { It is motivated me to learn more and give me } \\
\text { new knowledge or something that I have to } \\
\text { forget in a good way. }\end{array}$ \\
\hline Student 4 & & $\begin{array}{l}\text { I found new friends who can gain my } \\
\text { knowledge by learning from them. I learned } \\
\text { new things from them and also the tutors. } \\
\text { The tutors also gave some advices and } \\
\text { motivation to me. }\end{array}$ \\
\hline
\end{tabular}

As learning is not merely process of transferring material but also value, learning through online mode can be challenging. Students tend to feel the absence of lecturer during process of learning. There is no motivational speeches or story which commonly inserted by lecturer during the up and down of learning atmosphere. It happens probably because the lecturers are overwhelmed with so many students they have to deal with personally.

Mantiri (2015) states that the success on foreign language learning is infused with many factors as intelligence, attitudes, abilities, and motivation. Among them, motivation is the main factor affecting foreign language learning since it mediates the attitudes toward the target language and the outputs in the process of learning it. Although motivation is an essential part of the learning process, especially an autonomous one, researching on it is not enough. While the volume of research concerning motivation itself in psychology and education is vast, there have been very few source about learning English in online modality and motivation to learn it. Even thus, this situation remains a worldwide concern (Busse and Walter, 2013)

Since the online English community is flexible and it is not legally connected with scoring in the university; so, it can be less stressful and enjoyable by students. In addition, due to the 
flexibility of its learning process, the online English community can be designed based on students' mood and level of motivation. Therefore, the instructor tends to motivate students which positively correlated with their learning mood.

\subsection{Medium for sharing new information}

The third role of online English community is it can be used as a medium or place to provide various information which rarely discussed in the classroom, yet useful for students' education and growth. Since online English community is bondless with university curriculum and solely focuses on increasing students' English competence, various information that can improve students' knowledge can be freely added in the activity.

In this online English community, instructor inserts scholarship and study abroad information in the lesson by considering scholarship and study abroad is popular among students. Moreover, using scholarship information during the learning activity within online English community can bring positive washback in students' learning performance. As it is stated by Murr (2010) that the data from the pre-tests and post-tests on general learning suggest that the scholarship workshop used at Texas State University is an effective tool for increasing the knowledge of high school students with respect to completing a competitive scholarship application. Also, the results obtained from the general assessment indicate that the program's format, materials, and perceived benefit were well received by students. This is an important component to successful learning.

In addition, accessing new information interactively can be a problem during COVID-19 pandemic situation. The idea of online English community can be an alternative medium to share new informationnd this a can be seen in the excerpt below:

\begin{tabular}{|c|c|c|}
\hline Student 1 & : & $\begin{array}{l}\text { With this community, I can get many } \\
\text { knowledge and important informations even } \\
\text { though in this pandemic era. }\end{array}$ \\
\hline Student 2 & $:$ & $\begin{array}{l}\text { There are many experience and knowledge } \\
\text { that I got, particularly regarding international } \\
\text { scholarship. I like it very much. }\end{array}$ \\
\hline Student 3 & : & $\begin{array}{l}\text { I can improve my vocabulary, get new } \\
\text { friends, and of course I feel motivated to } \\
\text { study abroad }\end{array}$ \\
\hline
\end{tabular}

From the result of the questionnaire, it can be concluded that online English community can help students in providing a place for sharing. Since pandemic occurred in the beginning of the year, students dealt with a limited access toward an important information that can help them to reach their dream. Online English community is proven to be a useful place to share the up to date information.

\section{Conclusion and Suggestion}

It can be concluded that there are at least 3 (three) roles of online English community in pandemic era. The first is it can act as medium for English language exposure and practice. The existence of online learning community can be a supplement media for students to have a wider experience in term of English practice. Student will get more opportunity to learn and do some trials and errors which they can not acquire from classroom due to the time constraint. 
The second is to provide sufficient motivation. Motivation is crucial in boosting teaching and learning. However, the tight schedule and responsibility to finish all the material during teaching and learning makes this motivational injection from teacher to students is neglected. Online English community can solve that problem since it has more flexible program and time constraint.

The last role is the online English community can create a medium for sharing information. Teaching and learning is supposed to be an activity where information can be delivered from teacher and students rapidly. An information that probably is not inline with material directly but can support students learning development in the future. Online English community can make it possible to happen.

Regarding the conclusion, the writers would like to suggest several things. The first is, considering the availability of online English community within university to enrich exposure. English language learning demands a lot of exposure particularly interaction among teacher and students where it is quite challenging during pandemic. So, establishing this community may help students to gain more exposure in English.

Second, an intervention from faculty member to arrange the English community that inline with the university curriculum because online English community tends to be separated from curriculum and works in different direction. Of course, preserving its uniqueness is necessary. However, keeping it supervised by university can maintain (online) English community original goal that is as a support system to English teaching and learning.

Third, since this research is carried out by qualitative method, there will be another possible finding related to this topic from another research method. Moreover, this research is a case study from one university, increasing the number of participants for further study probably can give a wider perspective toward the same topic of research.

\section{References}

Atmojo, A. E. P. \& Arif Nugroho. (2020). EFL Classes Must Go Online! Teaching Activities and Challenges during COVID-19 Pandemic in Indonesia. Register Journal, 13(1), 49-76. https://scholar.google.co.id/citations?user=jiLCValAAAAJ\&hl=en.

Bahar, A. K., \& Latif, I. (2019). Society-Based English Community (Sobat): EFL Learners' Strategy in Learning and Practicing English Outside the Walls. Jurnal IImu Budaya, 7(2), 255-265. https://scholar.google.com/citations?user=nDsfFh8AAAAJ\&hl=id.

Brown, V. (2011). Changing demographics of online courses. US-China Educ. Rev. 8, 460-467. https://files.eric.ed.gov/fulltext/ED530681.pdf.

Busse, V and Walter, C. (2013). Foreign Language Learning Motivation in Higher Education: A Longitudinal Study of Motivational Changes and Their Causes. Modern Language Journal 97(2):435-456. https://maint.onlinelibrary.wiley.com/.

Cobigo, V, Lynn M., Rawad, M. (2016). Understanding Community. Canadian Journal of Disability Studies, 5(4). https://www.researchgate.net/publication/312186833 Understanding_Community.

Creswell, J. W. (2014). Research Design: Qualitative, Quantitative, and Mixed methods Approaches. London: Sage Publication, p. 32.

Dhawan, S. (2020). Online Learning: A Panacea in the Time of COVID-19 Crisis. Journal of Educational Technology Systems, 49(1), 5-22. https://journals.sagepub.com/doi/full/ 10.1177/0047239520934018.

Dhull, I and MS, Sakshi. (2017). Online Learning. International Education \& Research Journal, 3(8), 32-34. https://www.researchgate.net/publication/332833360_Online_Learning. 
Djalante, R. (2020). Review and analysis of current responses to COVID-19 in Indonesia Period of January to March 2020. Progress in Disaster Science. 6 (2020), 1-9. https://www.sciencedirect.com/science/article/pii/S2590061720300284.

Jones, A. \& Preece, J. (2006). Online communities for teachers and lifelong learners: A framework for comparing similarities and identifying differences in communities of practice and communities of interest. International Journal of Learning Technology, 2(2-3),

112-137. https://www.researchgate.net/publication/42792304_Online_communities_for_teac hers_and_lifelong_learners_A_framework_for_comparing_similarities_and_identifyi ng_differences_in_communities_of_practice_and_communities_of_interest.

Kumparan. (2020). Anies Tutup Sekolah di DKI Jakarta Selama 2 Minggu untuk Cegah Corona [Anies closes school in DKI Jakarta for 2 weeks to prevent Corona]. Retrieved from 24 (C)2020 The author and IJLTER.ORG. All rights reserved. https://kumparan.com/kumparannews/anies-tutup-sekolah-di-dki-jakartaselama-2minggu-untuk-cegah-corona-1t1V7X57VID

Mantiri, O. (2015). Key to Language Learning Success. Journal of Arts and Humanities. Vol. 04 No.

01:

14-18. https://www.researchgate.net/publication/273042792_Key_to_Language_Learning_ Success.

Murr, C.D. (2010). A Scholarship Workshop Program to Improve Underrepresented Student Access to Higher Education. Journal of Student Financial Aid, 40(2), 31-38. http://slideplayer.com/slide/3856089/.

Nur Agung, A.S., Surtikanti, M.W., OP, Charito A. Quinones. (2020). Students' Perception of Online Learning during COVID - 19 Pandemic: A Case Study on the English Students of STKIP Pamane Talino. Soshum: Jurnal Sosial dan Humaniora, [S.I.], 10(2), 225-235. http://ojs.pnb.ac.id/index.php/SOSHUM/article/view/1316.

Palys, T. (2008). Purposive sampling. In L. M. Given (Ed.) The Sage Encyclopedia of Qualitative Research Methods. (Vol.2). Sage: Los Angeles.

Rahiem, MDH. (2020). The Emergency Remote Learning Experience of University Students in Indonesia amidst the COVID-19 Crisis. International Journal of Learning, Teaching and Educational Research, 19(6), 1-26. http://www.ijlter.org/index.php/ijlter/article/view/2368.

Roddy, C. (2017). Applying Best Practice Online Learning, Teaching, and Support to Intensive Online Environments: An Integrative Review. Frontiers in Education: Digital Education, 2:59. https://www.researchgate.net/publication/321184426_Applying_Best_Practice_Onli ne_Learning_Teaching_and_Support_to_Intensive_Online_Environments_An_Integra tive_Review.

Sargsyan, M., \& Kurghinyan, A. (2016). The Use of English Language outside the Classroom. Journal of Language and Cultural Education, 4(1), 29-47. http://cejsh.icm.edu.pl/cejsh/element/bwmeta1.element.doi-10_1515_jolace-20160003. 